\title{
Narrative as an Alternative Teaching Approach of Moral Education
}

\author{
Norzihani Saharuddin ${ }^{1}$, Suhailah Hussein ${ }^{2}$, Maizura Yasin ${ }^{1}$ \\ ${ }^{1}$ Faculty of Educational Studies, Universiti Putra Malaysia, Serdang, Selangor, Malaysia \\ ${ }^{2}$ Kulliyyah of Education, International Islamic University Malaysia, Kuala Lumpur, Malaysia \\ Correspondence: Norzihani Saharuddin, Faculty of Educational Studies, Universiti Putra Malaysia, 43400 UPM \\ Serdang, Selangor, Malaysia. Tel: 603-9769-8210. E-mail: norzihani@upm.edu.my
}

Received: September 3, 2021 Accepted: September 28, 2021 Online Published: October 16, 2021

doi:10.5539/ass.v17n11p191 URL: https://doi.org/10.5539/ass.v17n11p191

\begin{abstract}
This paper discusses how the Narrative Approach has the potential to be one of the alternative teaching approaches in the teaching and learning process of Moral Education. This paper begins with an introduction to Moral Education in Malaysia. Also described in this paper is the history of how Moral Education in Malaysia began. Next, this paper discusses the Standard Curriculum and Assessment Document (DSKP) policy that drives the direction of the Education system in Malaysia in terms of, what is to be achieved and how it should be implemented in achieving the goals outlined. Then, the discussion continued by detailing the teacher training program for Moral Education teachers in Malaysia. Finally, this paper elaborates the description of the Narrative Approach and how its implementation in a teaching and learning process can provide the best added value to teachers and students; especially in producing 'student-centered' learning.
\end{abstract}

Keywords: narrative approach, teaching and learning, moral education, DSKP, student-centered

\section{Moral Education (ME): Malaysia Case}

Before the implementation of Moral Education (ME) in 1983 as a required school subject for non-Muslim students, Muslim students were instructed to commence Islamic Education. During that time moral education was instructed in a different formal and casual way. For example, moral education was officially instructed under Pendidikan Islam (Ugama Islam) for Muslim students whereas the non-Muslim students had a choice of learning religious matters, separate the ordinary educational timetable (Balakrishnan, 2010). Then, Civics Studies was presented in 1972, as a compulsory school subject to all students since Standard Four (10 years of age) to Form Three (15 years of age), however the civics components were joined in the Local Studies course for Standard One (7 years of age) until Standard Three (9 years of age). The Civics curriculum, which depended on the Rukun Negara and the Federal Constitution, was intended for inspiring patriotism, and furthermore to grasping and undertaking social issues. In 1970 The Rukun Negara was presented as the National Ideology and frames the formation of Malaysia's national approaches, as well as in the education field, until now.

In spite of that, the audit of the Cabinet Report (1979) which is the national training framework, found that the implementation of Civics as a school subject was not pleasing. As it is a non-exam subject, teachers and students seeming the subject to be less significant, consequently, in many schools the time allocated for Civics was substituted with the instructions of other subjects as the school examinations moved closer (Ministry of Education, 1979). However, in the middle of 1970s, there was an emerging worldwide alarm on the social problems among the youths that drew the attention of educationists (Mukherjee, 1983). Thus, schools could be the responsible party to nurture good character of the students. In Malaysia, these worries were correspondingly transferred in the Parliament which indicated that there was a necessity to give some types of good direction that educational institutes ought to manage (Mukherjee, 1983). Consequently, the Cabinet Report (1979) prescribed that, while the components of Civic ought to be coordinated in all subjects, ME ought to be presented as a subject for school examination. It stated;

In creating a disciplined, cultured and united people, the Cabinet Report (1979) suggested that by the time Muslim students learn Islamic Knowledge, non-Muslim students should be taught Ethics and Moral Education. They have to sit for an exam for this subject. Through these two subjects, respect for the individual and freedom to embrace any religion in a multi-religious society should be nurtured (Ministry of Education, 1979, p. 49).

To explain the proposal in the Cabinet Report, the Ministry of Education (MOE) submitted the New Primary 
School Curriculum (known as KBSR) in 1983 and the New Integrated Secondary School Curriculum (known as KBSM) in 1989. Through KBSR and KBSM, Moral Education (ME) was first introduced as a compulsory school subject for non-Muslim students at the primary and secondary school levels. Thus, starting at that time, the ME syllabus underwent two remarkable changes, namely in 2000 and 2010.The structure of Moral Education (ME) in Malaysia is based on the noble values (known as Nilai Murni) that are imperative to Malaysian plural society. For this situation, the Nilai Murni refers to values that depend on different religions, conventions and societies of various groups (Ministry of Education, 1983). These values would stipulate the standard to characterize good or honourable character and capable peoples that will empower them to lead a satisfying life and contribute towards the peace and harmony in Malaysia.

In Malaysia, this arrangement of values appears to change with every modification of the national educational programs. In the primary as for the Moral Education syllabus of 1983, there remained 16 core values and 64 sub values ( 80 values in total). However, in the 2000 ME syllabus, there were 36 values and further in the 2010, ME syllabus for elementary schools consisted of only 14 values. This brought up the issue of the rundown of set values and in addition the quantity of values that would be fused in the ME syllabus for secondary schools. Apparently, these values have been instructed to promote moral thinking/reasoning, moral feeling and moral behaviour. Therefore, the Moral Education in Malaysia seems to take the structure of character instruction that expands on moral values that are essential in building character together with applying moral thinking, feeling and action/act in daily life.

However, The Standard Based Curriculum for Secondary Schools (KSSM) which was implemented in 2017 has replaced the Integrated Curriculum Secondary School (KBSM) which began in 1989. KSSM was formulated to meet the new policy requirements under the Malaysia Education Blueprint (PPPM) 2013-2025 to the quality of the curriculum implemented in secondary schools is in line with international standards. International standards-based curriculum has been incorporated into KSSM through the drafting of the Curriculum and Assessment Standard Document (DSKP) for all subjects containing Content Standards, Learning Standards and Performance Standards. Efforts to incorporate assessment standards into curriculum documents have changed the landscape of history since the National Curriculum was implemented under the National Education System. Continuing students can be assessed on an ongoing basis to identify their level of mastery in a particular subject, as well as enabling teachers to take follow-up actions to improve student achievement.

The DSKP has also integrated the six pillars of the KSSM Framework, which is integrating knowledge, skills and values, as well as explicitly incorporating 21 st century skills and higher order thinking skills (HOTS). The integration is planned to produce people who are intellectually, spiritually, emotionally and physically balanced as has been demanded in the Malaysia National Education Philosophy. In order to be efficacious in implementing KSSM, teachers' teaching and learning should emphasize the Inquiry-based Learning and Project-based Learning approach, so that students can master the skills that are required in the 21st century. It is an expectation by the Ministry of Education (MOE) that the implementation of KSSM will achieve the aims and objectives of the National Education System as a whole. As Malaysia National Education Philosophy stated that;

Education in Malaysia aims to develop the ability of individuals holistically on an ongoing basis, to produce balanced individuals in terms of intellectual, spiritual, emotional and physical, based on strong faith and loyalty to God. The measure is taken to produce Malaysian citizens who are knowledgeable and competent, have high moral standards, responsible human beings who are able to achieve high personal well-being and able to contribute to the harmony of the family, society and the country in general. (Ministry of Education Malaysia, 1988)

\section{Standard Curriculum and Assessment Document (DSKP)}

The subject of Moral Education (ME) is an effort to teach students to be moral and ethical persons by emphasizing the developmental aspects of moral reasoning, moral emotion and moral conduct. It is expected that this course will produce students who are knowledgeable, dignified, and of a patriotic unity and enthusiasm towards contributing effectively to themselves, their families, their community and their country.

The Moral Education (ME) curriculum is realized through the Standard Curriculum and Assessment Document (DSKP) which is a mandatory document that every teacher must refer to, in order to plan and evaluate their teaching and learning. Therefore, teachers need to plan to translate this DSKP wisely to make teaching and learning more effective and attractive. In addition, teachers need to understand the level of mastery outlined in the DSKP and should always ensure that these levels of mastery are grasped by the students.

The DSKP's curriculum also provides understanding and appreciation and ensures that students practice universal values in the religions, traditions and customs of the various races and laws of this country. The 
curriculum also offers a guide for students to make decisions and actions that empower them to perform moral and social responsibilities toward society, the country and as well as the world. It is also in line with the three moral principles, altruistic, autonomous and fair, which is crucial in building-up and maintaining a moral and ethical society. In this DSKP, there are 18 universal values that have been included in the Moral Education curriculum.

Besides, the DSKP also emphasizes the skills that the students need to acquire in order to prepare them for the challenges of the 21st century through the teaching and learning process of Moral Education. The mastery of these skills will help the students to build up their self-confidence in their daily lives. Thus, various teaching and learning approaches are also recommended to teachers in order to ensure their students experience a more meaningful Moral Education curriculum. The DSKP also emphasizes the understanding of the values of cohesion and good relations among people in order to produce a peaceful and harmonious citizenry.

Thus, together with the DSKP, the focus of KSSM Moral Education is to build a high standard moral character of the students. The development of this noble human being can be realized by adopting three moral domains, namely moral reasoning, moral emotion and moral conduct among students. Actions reinforced by moral reasoning allow students to think before acting. Moral emotions will motivate students to engage in moral action. Thus, in this way the moral conduct of a student will lead to a man of noble character. This moral domain will also encourage a student to make appropriate, accurate and consistent moral judgments. Moral considerations are a key aspect of moral formation that enables students to take action based on universal rules or values.

\section{Moral Education Training for Teachers in Malaysia}

Preparing learners for their character and values development is a vital part of the instruction process. Every teacher is a moral agent and has a great responsibility to nurture the moral development of their students. Therefore, instructors-teachers play a critical part in cultivating moral development in students. According to Ryan (1975), instructors (lecturers) have a commitment to enable pre-service teachers to get the most effective approach to make "ethical educational modules" in the classroom. The substance of teacher training must encompass more than scholastic substance plus educational aptitudes (Ryan, 1975).

In Malaysia, the University of Malaya (UM) was the early institution to provide a Moral Education course in their undergraduate programme. Moral Education was open as a minor course at the Faculty of Education at UM. Initially, the Moral Education course was offered under the Bachelor of Education (Teaching of English Language as Second Method) programme in 1989 and later in 2001 it was offered under the Bachelor of Education (Teaching of Tamil Language) programme (Chang, 2003).

In Universiti Putra Malaysia (UPM), the Faculty of Educational Studies has offered Moral Education as a minor programme since 1999 for students of Bachelor of Education. Meanwhile, at the postgraduate level, the master's program in the field of Moral Education has been offered since 1996. In the same year, 1996, International Islamic University Malaysia (IIUM) started to offer Bachelor Education specializing in Moral Education for the Teacher Graduation Special Program (Program Khas Pensiswazahan Guru - PKPG) and after that, retains it as a minor for the Bachelor Education Degree programme until now. Finally, in 2005, three public universities including Universiti Putra Malaysia (UPM), Universiti Utara Malaysia (UUM) and Universiti Pendidikan Sultan Idris (UPSI) started to offer Moral Education as a major in their Diploma and Bachelor of Education programmes.

Although this subject has been embedded in the school system for almost three decades, most of the teachers who teach Moral Education in primary and secondary schools are not among the teachers with special experience in Moral Education teacher preparation programs, sometimes the course is taught by teachers from specialization of other subjects (Balakrisnan, 2014). According to Balakrisnan (2019), a study she conducted in 2013 and 2016 on Moral Education found that 50 percent of teachers who teach Moral Education in primary and secondary schools do not have formal qualifications as Moral Education teachers. Most of the teachers were asked to teach the subject simply because they had an empty slot in their timetable. This would be very surprising if it still happens to this day. This suggests that Moral Education is viewed as a light and easy subject, where any teacher regardless of specialization background is qualified to teach it formally in the classroom. The truth is, Moral Education should be taught by teachers who are well-trained from the aspects of teaching and learning (content, pedagogy, skills, assessment, curriculum etc) of Moral Education (Chang, 2010). Moreover, Moral Education is taught to students with multi-ethnic backgrounds, therefore teachers are required to have special expertise in ensuring that it can be delivered as well as possible. Apparently, teachers hired to teach this course must have adequate qualification in terms of knowledge, skills and enthusiasm in developing the domain of moral development of students (thoughts, feelings and moral actions). A study by Sanderse and Cooke (2021) 
found that acting on moral grounds is not an easy thing, especially if the teacher needs to teach it during the class, and he or she is not a specialized teacher in the field of Moral Education. This is because teachers' education programmes focus primarily on mastery of subject -specific content rather than teaching values as a whole. This reinforces that Moral Education needs to be taught by professionally qualified teachers in the field of Moral Education.With the intention of be more serious in implementing Moral Education as an official subject, the Ministry of Education (MOE) and other organizations such as universities and teacher training institutions need to be serious in expanding and exploring the methods of this subject in their teachers' education programme to provide teachers with professional knowledge and skills as subject specialists.

\section{The Narrative Approach}

According to Diekelmann (2001), the Narrative Approach is not just about using storytelling as a strategy for learning, nor is it a teaching strategy as such. Narrative Approach is an approach by gathering all the pedagogies (including traditional) into converging conversation such that the possibility for anything to show itself is held open (Diekelmann, 2001). In addition, Narrative Approach is an alternative pedagogy that invites active students' participation in learning and empowers them to take more control in their learning while promoting their reasoning skills (Dahlberg, Ekebergh, \& Ironside, 2003).

As stated above, approach is often understood as teaching methods. However, in this Narrative Approach, 'approach' is more as a way of thinking about and comportment within education (Ironside, 2003). Therefore, approach in this sense, can be considered more as an epistemological aspect in learning and teaching in the Moral Education teacher programme. Narrative Approach is not a strategy to be implemented, but rather a way to create an environment within teacher's education that invites lecturers, preservice teachers, and their former experiences into converging conversations (Dahlberg, Ekebergh, \& Ironside, 2003).

According to Diekelmann (2001), Narrative Approach is a site-specific process to teaching, learning and schooling. Furthermore, the Narrative Approach is specific for two reasons. Firstly, Narrative Approach challenges the assumptions inherent in conventional approaches. However, these assumptions are different from school to school. Secondly, one of the aims of Narrative Approach is to create opportunities for instructors and learners to engage in conversations about what is going well and what is not (moral issues). Yet, these conversations will differ from one educational setting to another. In the current study, using Narrative Approach in preparing Moral Education teachers has broadened the opportunity for the preservice teachers to groom their moral reasoning.

Apparently, the produced solutions are not generalized to all kinds of schools or classrooms, but the processes of Narrative Approach are transferable and can be enacted in any school or classrooms (Andrews et al., 2001). Narrative Approach is dedicated to reducing the power of the instructor-teacher, which means students have a voice on determining how the course is taught; as a result, they are encouraged to participate in the learning activities. Hence, by implementing Narrative Approach in the Moral Education field, or even in preservice teachers' programme, moral experiences (stories) or cases become tools for learning in the classroom. Besides, by critiquing and interpreting these stories/cases results in meaning-making activities, they ultimately lead to deeper learning that would promote preservice teacher's moral reasoning (Swenson \& Sims, 2000).

Subsequently, engaging in a Narrative Approach learning environment could play a significant role in a curriculum. Thus, the Narrative Approach will provide two pedagogical goals, namely as learning efficiency and enthusiasm. The concept of learning efficiency has grown noticeably recently as teachers-instructors started to adapt constructivist learning in their teaching and learning processes, which highlights on knowledge creation instead of repetition instruction (Mayer, 1989).

Thus, Piaget (1954) asserted that due to the active narrative feature, by way of engaging students in a captivating world inhabited by diverse characters, this would encourage students to participate in extraordinary measures such as; first, co-construction (participating in narrative construction), second, exploration (actively engaging in narrative exploration by seeing how characters' intentions influence their actions in the evolving narrative), and finally, reflection (engaging in post-hoc analysis activities by reflecting the narrative experience and the theme). These three procedures are considered as significant steps in promoting cognitive development such as moral reasoning ability among students.

\section{Narrative as a Teaching Approach in Moral Education}

It is essential to a moral education teacher to know tremendous approaches to teach Moral Education as according to Abdul Rahman Md Aroff (1985), teachers cannot depend on only one single approach to moral education as an attempt to educate pupils' morality or in promoting them to develop morally. In fact, according 
to Hersh, et al. (1980), each one of the main approaches to moral education has its weaknesses (and strengths too) for examples; Rationale-Building Approach, Farmington Trust project, Value Analysis Approach, Values Clarification Approach, Humanities Curriculum Project and Cognitive Moral Development approach.

Until now, the Cognitive Developmental Approach is still the most favoured Moral Education teaching approach in Malaysia and other countries. As a result, it is not an easy task to introduce the Narrative Approach as one of the alternative approaches in Moral Education. However, according to Tappan (1990), it was relevant to implement the Narrative Approach as one of the teaching approaches in teacher education programme as this approach has been proven beneficial in developing moral reasoning abilities in other educational programme (for instance, nursing education programme). In fact, as future teachers, especially Moral Education teachers, preservice teachers should be trained to have a well-developed moral reasoning skill to support their future students to also have a good moral reasoning capability. As Kohlberg (1976) claims, an instructor that have higher levels of moral reasoning skills will be able to perform teaching and learning processes more attractively and it is valuable in promoting students' moral reasoning skills.

Consequently, Tappan (1990) cited that the Narrative Approach is an approach of teaching that delivers an alternate way of learning for students. This was because the use of Narrative Approach in teaching and learning activities is more to practice the elements of using narrative to form an environment that offers students, teachers, and their former experiences into converging conversations to enhance student's learning experiences. For example, by learning to understand situations in the context of students' moral experiences and applying the knowledge learned through traditional methods in a moral education classroom, there is a stronger emphasis on critiquing, examining, exploring, and deconstructing moral situations that students have experienced. Thus, all these techniques would promote students' moral reasoning competencies as well.

Additionally, the strong point of the Narrative Approach is the opportunity to interconnect and share contextual ideas related to ethics, values, culture, and relationships to create changes and actions within the students and instructors as well. Furthermore, by practicing Narrative Approach in the Moral Education classroom, it could enable the process of gaining the attention of students by exposing them to moral experiences and problem-solving exercises. In the Narrative Approach, students are also required to share their moral stories (experiences), develop a sense of community, explore the personal and professional roles in their lives, in which these criteria will help them engage in moral reasoning. Hence, through practising an open discussion in the Narrative Approach, students will obtain chances to engage with each other and collaborate to interpret the meaning of their moral experiences.

Undeniably, the use of Narrative Approach in educational settings around the world is wide spreading lately. For example, in the Japanese former school system, the concept of learning is more to a teacher-centred emphasis. However, this concept has minimized the students' ability to practice self-directed concepts which is vital in higher education. Therefore, in a Japanese universities conference in 2002, scholars discussed the need to evaluate and modify their educational practices to give students better learning experiences especially in promoting their moral reasoning skills. One of the suggestions was to implement the Narrative Approach together with the traditional method of teaching and learning in teaching and learning processes (Kawashima, 2005). They believe by this way, students and instructors will acquire chances to share their life experiences and get a lot of benefits through their discussions. Narrative Approach is useful in assisting the students to be more open in sharing their perspective in teaching and learning processes, as Wells (1986) points out;

Organizing stories in the mind or even storytelling, is one of the most important ways to make-meaning; Thus, it is an activity covering all aspects of learning.... Through sharing narratives, teachers and students can share their understanding of an issue and make their mental model of the world closer. In other words, stories, and narration are relevant in all areas of the curriculum, in developing students' reasoning potential (Wells, 1986, p. 194).

Accordingly, by integrating the Narrative Approach into Moral Education teachers' programme, it is presumed that it would assist preservice teachers to appreciate their differences of moral experiences, views, cultural background and let them develop a professional identity as future Moral Education teacher with a competence level of moral reasoning. The reason is, through critical analysis of other narratives and by expressing their own moral stories, the preservice teachers will be able to gain insights regarding their own experiences and others, and finally engage their moral reasoning as well.

Apparently, another field that has implemented Narrative Approach dedicatedly as their teaching approach is the nursing and midwifery schools in Australia. Nancy Diekelmann (2001), who is a leader in nursing education research, has introduced the Narrative Approach while conducting study in nursing education. She strongly held that the crucial framework of the Narrative Approach is the concept of 'caring in community'. This means that 
the purpose of Narrative Approach is to achieve consideration of phenomena through clarification (Seaton, 2005). Another scholar who is a proponent of the Narrative Approach is Dinkins (2005). She remarked that the Narrative Approach is not a method at all but a mode of understanding, that leads learners to involve in making-meaning actions, thus, promoting their moral reasoning ability.

\section{Conclusion}

This paper explores the elements and concepts that can be used as the foundation of research in teacher training program especially for Moral Education teachers. The overview of DSKP's policy that has connection to the pedagogical approach which supports the Moral Education in Malaysia also have been discussed in this paper. Then, this paper examined the background of the existing Moral Education program in Malaysia, in a way to provide an understanding on the rise of the Narrative Approach in Malaysia context. Subsequently, by using the Narrative Approach in Moral Education setting, it is hoped to offer an approach for teaching and learning in terms of inviting instructors and pre-service teachers to seek new meanings of their education experiences. Therefore, it could lead them to acquire better moral reasoning skills on the way to prepare for better future Moral Education teachers. Therefore, hopefully this paper could offer some insight to find the best way to make an alternative teaching approach such as Narrative Approach to be more successful in teaching and learning of Moral Education.

\section{References}

Andrews, C. A., Ironside, P. M., Nosek, C., \& Sims, S. L. (2001). Enacting narrative pedagogy: The lived experiences of students and teachers. Nursing Education Perspectives Journal, 22(5), 252-259.

Aroff, A. R. M. (1984). Matlamat pendidikan moral: Suatu penilaian terhadap matlamat projek Pendidikan Moral di Malaysia. Jurnal Pendidik dan Pendidikan, 6, 52-59.

Balakrishnan, V. (2010). The development of Moral Education in Malaysia. Journal of Educators \& Education, 25(1), 89-101.

Balakrisnan, V. (2019, April 27). The debate continues. New Strait Times: Malaysia Edition. Retrieved from https://www.nst.com.my/opinion/letters/2019/04/483551/debate-continues

Dahlberg, K., Ekebergh, M., \& Ironside, P. M. (2003). Converging conversations from phenomenological pedagogies: Toward a science of health professions education. In N. Diekelmann, \& P. Ironside (Eds.), Teaching practitioners of care: New pedagogies for the health professions (Vol. 2, pp. 22-58). Madison: University of Wisconsin Press.

Diekelmann, N. (2001). Narrative pedagogy: Heideggerian hermeneutical analyses of lived experiences of students, teachers, and clinicians. Advances in Nursing Science, 23(3), 53-71. https://doi.org/10.1097/00012272-200103000-00006

Dinkins, B. D. (2005). Narrative pastoral counseling. New York: Xulon Press.

Dvir, N. (2021). Using narrative pedagogy for novice teachers' professional development. Professional Development in Education, 1-13. https://doi.org/10.1080/19415257.2021.1895285

Hersh, M., \& Miller, J. F. (1980). Model of Moral Education · An appraisal. New York: Longman Inc.

Kawashima, A. (2005). The implementation of narrative pedagogy into nursing education in Japan. Journal of Nursing Education Perspectives, 26(3), 168-171.

Kohlberg, L. (1976). The cognitive-developmental approach to moral education. Journal of The Phi Delta Kappan, 56(10), 670-677.

Mayer, R. E. (1989). Models for understanding. Review of Educational Research, 59(1), 43-64. https://doi.org/10.3102/00346543059001043

Ministry of Education, Malaysia. (1983). Moral education syllabus for primary school Malaysia. Kuala Lumpur: Curriculum Development Centre.

Ministry of Education, Malaysia. (1988). Moral education syllabus for secondary school Malaysia. Kuala Lumpur: Curriculum Development Centre.

Ministry of Education, Malaysia. (2010). Moral education syllabus for primary school. KSSR. Putrajaya: Curriculum Development Division

Ministry of Education, Malaysia. (2017). Dokumen Standard Kurikulum dan Pentaksiran Pendidikan Moral KSSR Tahun 6. Putrajaya: Curriculum Development Division 
Ministry of Education, Malaysia. (2017). Dokumen Standard Kurikulum dan Pentaksiran Pendidikan Moral KSSM Tingkatan 4 dan 5. Putrajaya: Curriculum Development Division

Ministry of Education, Malaysia. (2017). Moral education syllabus for primary school. KSSR. Putrajaya: Curriculum Development Division

Mukherjee, H. (1983). Moral education in a plural society: Malaysia. Journal of Moral Education, 12(2), 125-130. https://doi.org/10.1080/0305724830120209

Piaget, J. (1954). The construction of reality in the child. New York: Basic Books. https://doi.org/10.1037/11168-000

Sanderse, W., \& Cooke, S. (2021). Being Prepared to Become a Moral Teacher: UK Teachers' Experiences of Initial Teacher Education. Scandinavian Journal of Educational Research, 65(2), 226-239. https://doi.org/10.1080/00313831.2019.1664628

Seaton, D. (2005). Narrative in music: The case of Beethoven's "Tempest" Sonata. In J. Ch. Meister (Ed.), Narratology beyond literary criticism: Mediality, Disciplinarity, Meister (pp. 65-82). Berlin and New York: De Gruyter. https://doi.org/10.1515/9783110201840.65

Swenson, M. M., \& Sims, S. L. (2000). Toward a narrative-centered curriculum for nurse practitioners. Journal of Nursing Education, 39(3), 109-115. https://doi.org/10.3928/0148-4834-20000301-05

Tappan M. (1990). Hermeneutics and moral development: Interpreting narrative representations of moral experience. Journal of Developmental Review, 10, 239-265. https://doi.org/10.1016/0273-2297(90)90012-S

Wells, G. (1986). The meaning makers: Children learning language and using language to learn. Portsmouth: Heinemann Educational Books Inc.

\section{Copyrights}

Copyright for this article is retained by the author(s), with first publication rights granted to the journal.

This is an open-access article distributed under the terms and conditions of the Creative Commons Attribution license (http://creativecommons.org/licenses/by/4.0/). 